\title{
West Syndrome: Report of Clinical Case: 9 Years of Follow-up
}

\author{
Sindrome de West: Relato de Caso: \\ 9 anos de Acompanhamento
}

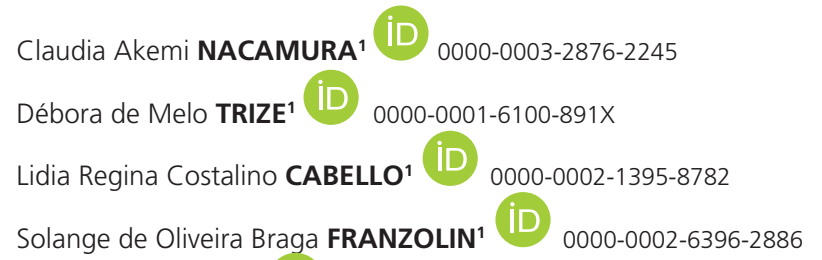

Sara Nader MARTA ${ }^{1}$ iD 0000-0002-7094-941X

\section{ABSTRACT}

West Syndrome is one of the rare and severe childhood epilepsies, starting in the first year of life and having an uncertain etiology. Even if some of the symptoms are missing, a triad of them defines West Syndrome, including epileptic spasms, arrest or regression of psychomotor development, and hypsarrhythmia on interictal electroencephalography. The objective of this study was to obtain updated data on West Syndrome literature and report a clinical case of a patient with the medical diagnosis of this syndrome, with gastrostomy feed tube, and clinical pattern of spastic quadriplegia. Initial clinical examination showed prolonged retention of deciduous teeth, periodontal disease, poor oral hygiene, mouth breathing, deep palate, anterior open bite, tongue interposition between the dental arches, and low caries experience. Over 9 years the patient presented complications in their sistemicas conditions, with need for gastrostomy and many periods of hospitalization that determined periods of absence for the dental monitoring. Despite this, currently his oral health condition is good and stable. Dental care for people with disabilities should be developed, encouraged and continuously extended, in agreement with the constitutional principles of human dignity and the rights for health and equality.

Indexing terms: Dentistry. Oral health. Spasms, infantile.

\section{RESUMO}

A Sindrome de West é uma rara e severa forma de epilepsia da infância, com início no primeiro ano de vida e etiologia ainda não definida. Mesmo com a ausência de alguns sintomas, a tríade que define a Sindrome de West é a presença de espasmos, retardo no desenvolvimento psicomotor e a presença da hypssarritmia no eletroencefalograma. O objetivo deste estudo foi a obtenção de dados atualizados na literatura sobre a Síndrome de West e relatar um caso clínico de um paciente com diagnóstico médico dessa síndrome, com gastrostomia e padrão clínico de quadriplegia espástica. No exame clínico inicial observou-se retenção prolongada de

$\because \nabla$

1 Universidade do Sagrado Coração, Curso de Odontologia. Rua Irmã Arminda, 10-50, Jardim Brasil, 17011-160, Bauru, SP, Brasil. Correspondência para / Correspondence to: SN MARTA. E-mail: <sara@nadermarta.com.br>.

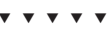

Como citar estar artigo / How to cite this article

Nacamura CA, Trize DM, Cabello LRC, Franzolin SOB, Marta SN. I. West syndrome: report of clinical case: 9 years of follow-up. RGO, Rev Gaúch Odontol. 2018;66(4):369-374. http://dx.doi.org/10.1590/1981-8637201800040000113450 
dentes decíduos, doença periodontal, padrão pobre de higiene bucal, respiração bucal, palato profundo, mordida aberta anterior, interposição de língua entre os arcos dentais e baixa experiência de cárie. Ao longo de 9 anos o paciente apresentou complicações nas suas condições sistêmicas, com necessidade e realizar gastrostomia e com muitos períodos de internação. Apesar disto, atualmente sua condição de saúde bucal é boa e estável. Os cuidados odontológicos para pessoas com deficiência devem ser desenvolvidos, encorajados e estendidos continuamente, de acordo com os princípios constitucionais da dignidade humana e os direitos de saúde e de igualdade.

Termos de indexação: Odontologia. Saúde bucal. Espasmos infantis.

\section{INTRODUCTION}

West Syndrome (WS) and Infantile Spasms (IS) are often used as synonyms [1]. WS is a rare and severe childhood epilepsy syndrome. Even if some of the symptoms are missing, WS is defined by a triad of them, including epileptic spasms, arrest or regression of psychomotor development, and hypsarrhythmia on interictal electroencephalography (EEG) $[2,3]$. WS was one of the first epilepsy syndromes described. The name of WS was given in honor of the English physician William James West. In 1841, he described his own son's problems to The Lancet. WS was not recognized as an epileptic disorder until 1950 when Gibbs et al. described the pathognomonic feature of EEG with hypsarrhythmia [1]. The full description of the syndrome was made in 1951 by Vazques and Turner that correlated the clinical findings to standard hypsarrhythmia to stroke EEG [4].

The diagnosis of WS is usually easy, but the determination of the etiological factor can be difficult and this has a profound impact on the treatment and prognosis [1]. WS can be classified into three categories based on the etiology of IS [1,3]: symptomatic spasms (etiology can be identified in more than $70 \%$ of cases, such as hypoxic ischemic encephalopathy); cryptogenic (etiologic diagnosis cannot be identified and normal development precedes the spasms) $[1,5]$. The term idiopathic was used to describe patients with normal development at the onset, normal examination and neuroimaging, and a hypsarrhythmia pattern without focal abnormalities. The most recent proposal by the Commission on Classification and Terminology of the International League Against Epilepsy (ILAE) proposes replacing these terms with specific etiologic categories: genetic, structural/metabolic, and unknown [5]. Many patients are delayed in their development and have evidence of Cerebral Palsy (CP) [1].

The incidence of WS is 1 per 2000-4000 individuals born alive. It is more frequent in males; it is responsible for $2-10 \%$ of the causes of childhood epilepsies [2] and can be associated with other systemic conditions or syndromes [6]. WS occurs in children from all ethnic groups [3].

There is an abrupt onset and a gradual evolution, manifesting usually before the first year of life, from 4 to 8 months of age. Some epileptic syndromes, such as WS, can evolve catastrophically by a major impact on the cognitive and neuromotor development of the patients due to the difficulty in controlling the crisis and the association with intellectual disabilities [1]. The presence of mental retardation is observed in $90 \%$ of the cases, half of the patients with severe mental disabilities; psychiatric disorders are common; $50-60 \%$ of the cases developed into Lennox-Gastaut syndrome; multifocal epilepsy; or secondarily generalized partial epilepsy [2].

There are two drugs with evidence of efficacy in the treatment of WS: ACTH hormone and the Vigabatrin $[1,7]$. Pyridoxine, Valproic Acid, Lamotrigine, Topiramate, Prednisone, Phenobarbital [7], Carbamazepine, or Phenytoin $[1,2]$ are also used.

Several studies show that the prevalence of periodontal disease, caries, malocclusion, and the amount of biofilm are higher in patients with the neuromotor deficit than in the average population [8]. In the presence of intellectual and physical deficits in individuals with WS, preventive care is necessary to avoid dental problems [3]. There is no peculiar oral change on people with WS, The frequently observed changes are periodontal disease, bruxism, and trauma [9].

Bruxism is frequently reported in patients in need of special care and with neuromuscular disorder [3]. In children with WS - who lack motor coordination or who have the neurological developmental delay, and cognitive and communication deficits -, inadequate oral hygiene presents an additional challenge to the dentist and often has profound mental and physical deficits [3]. Oral health status can also be improved if the family is daily involved with oral hygiene [6] routines. 


\section{CASE REPORT}

Through this clinical case, we aimed to elucidate the various oral clinical manifestations, associating them with some dental findings, and giving emphasis to early intervention and treatment. The images and clinical case data used in this study were authorized by the patient's legal guardian and approved by the Research Ethics Committee, number 1.514.545.

Systemic conditions: The patient's mother reports his clinical course of Cerebral Palsy (CP) (figure 1A). He was diagnosed as a case of WS, having spastic quadriplegic $\mathrm{CP}$ with severe intellectual impairment. He is unable to communicate verbally; he presents difficulties in understanding and concentrating; and presents signs of restlessness and very poor motor skills. The review of his medical history revealed a regular use of Sonebon (Nitrazepan) and Depakene (Valproic Acid). In 2007, the patient had no seizures during the year.

During the mother's patient pregnancy, bleeding was reported in the 4th month. The child was born by cesarean, at term, and did not accept breastfeeding. His first seizure occurred on his second day of life and the diagnosis of WS was raised during the child's health care consultation when he was 2 months old. The diagnosis of
WS was based on an EEG test, which found hypsarrhythmia and infantile spasms (figure 1B).

His mother made his report informing that he had difficulty in chewing and mouth breathing. Neuropsychomotor delay is an evident characteristic.

Later in 2007, the patient had post-orthopedic surgery complications, having to recover and he only returned to follow up one year and four months later. In 2011, he started to use a gastrostomy tube due to dysphagia and, since then, the patient does not eat orally. In that same year, he was hospitalized with pneumonia. Then, in 2015 , seizures reoccurred; after many searches for orthopedic surgery in the column, which was contraindicated, with well-marked scoliosis with lung compression. In addition, in 2016, the patient started coming with a nasal tube for oxygen due to difficulty with breathing, especially when nervous, with a chance of becoming cyanotic.

Oral conditions: An initial intraoral clinical examination found only that a deciduous molar had incipient caries (low caries experience). Additionally, showed periodontal disease, poor oral hygiene, deep palate, anterior open bite (figure 2), dry lip-mouth breathing (figure 3), tongue interposition between the dental arches. The patient presented movements similar to chewing, possibly by saliva swallowing difficulty; teeth
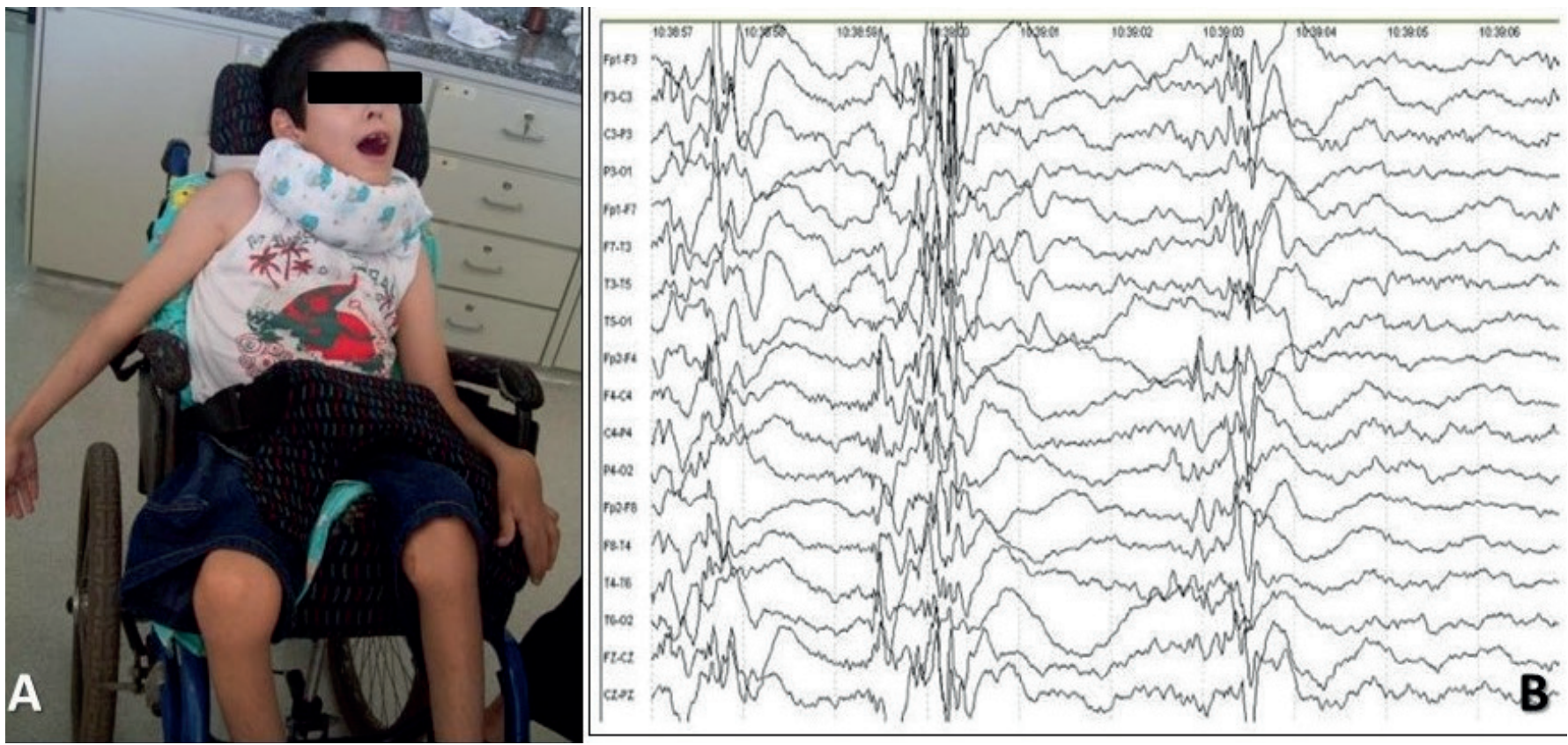

Figure 1. A) Patient male 9 years old with cerebral palsy; B) EECG of patient: hypsarrhythmia and infantile spasm. 
with gingival enlargement; plaque accumulation; gingivitis; supragingival calculus on all surfaces of the teeth; alteration in the chronology of tooth permanent eruption; bruxism and poor motor skills. (figure 4).

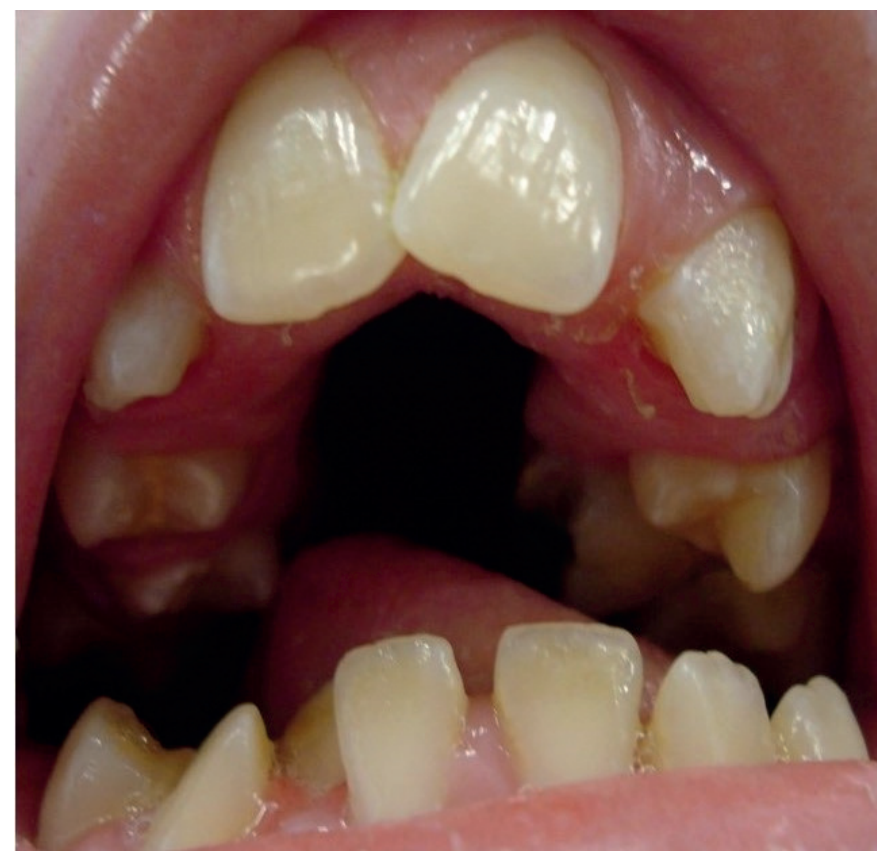

Figure 2. Oral conditions: poor oral hygiene, deep palate, anterior open bite.

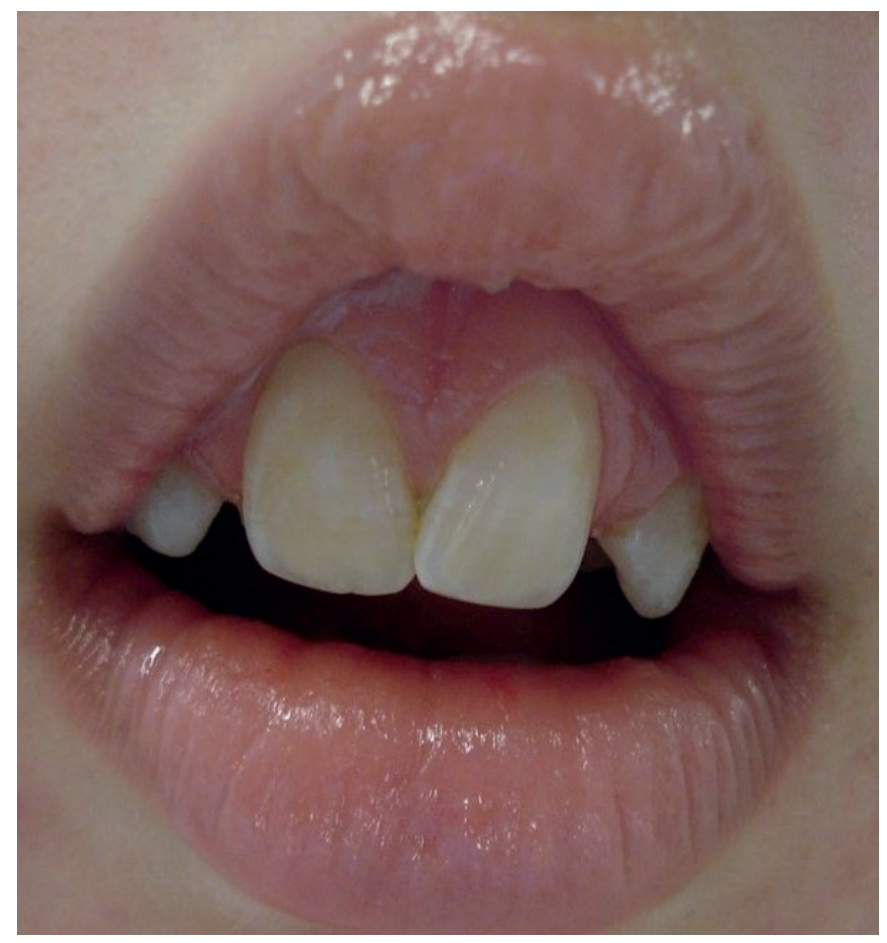

Figure 3. Presence of dry lip-mouth breathing.

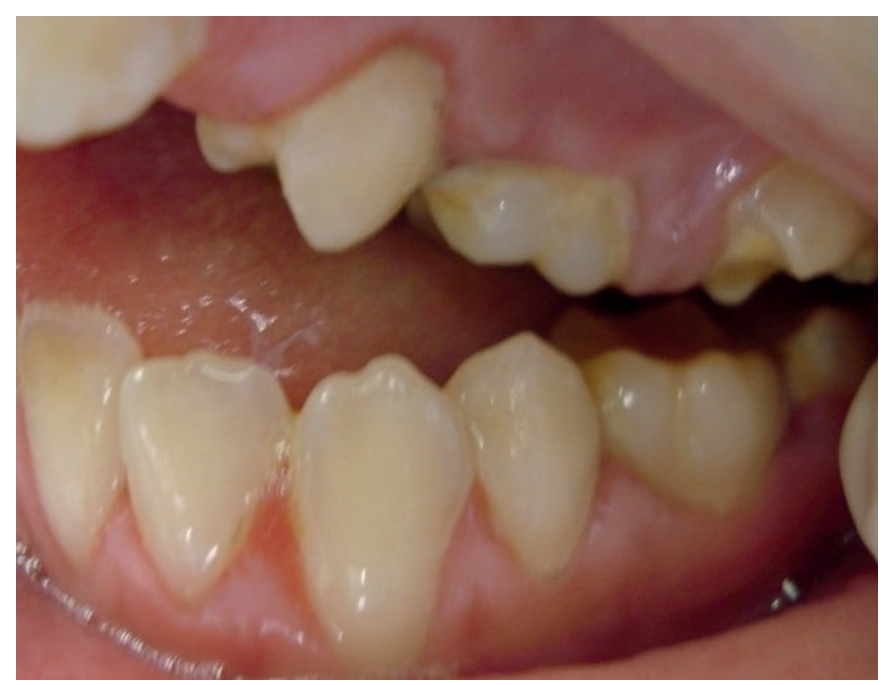

Figure 4. Presence of teeth with gingival enlargement; plaque accumulation; gingivitis; supragingival calculus on all surfaces of the teeth; alteration in the chronology of tooth permanent eruption.

The patient is a little contributor to dental treatment. $\mathrm{He}$ is always seemed nervous, lacked concentration and presented difficulties in understanding, and he was not able to communicate and obey commands. His mother reported difficulties in performing oral hygiene on her child, justifying that he cannot cooperate: he has insufficient mouth opening, and he clenches and grinds his teeth; she also reported difficulties in positioning him. In addition the child's mother was too afraid of triggering seizures when the child was agitated. There was a low experience of caries in the primary dentition and an absence of dental caries in the permanent dentition until the time of evaluation.

The dental treatment consisted of preventive measurements such as proper oral hygiene along with his mother and management of a dental professional.

The patient is more comfortable with the head turned to the left, with his backrest left in 45 degrees due to respiratory distress and dysphagia. To improve the visual field, the procedures are done with the dentist chair positioned on the left side of the dental chair.

The noise of the dentist's low-speed handpiece and the act of taking pictures makes him nervous, which leads to breathing difficulties. The extraction of deciduous teeth with prolonged retention was performed to prevent its aspiration. The control of the permanent teeth eruption was accompanied. In addition, prophylaxis and restorations of the decayed teeth were performed with glass ionomer cement. The patient's mother was instructed in caries and 
how to prevent periodontal diseases. She was also advised to bring the patient for recall visits every 2 months if his health condition permitted.

At 15 years old, after 1 year of absence, due to complication with his health, the patient returned with very precarious oral hygiene, the presence of dental plaque, tartar, and gingivitis, when scraping and dental prophylaxis were performed.

During the procedures, due to his health condition, some additional measures were implemented: the direct use of waterway syringe was avoided; close attention was given to the aspiration of saliva, physiological, prophylactic paste serum, gauze moistened with saline was used to remove residues.

Today, the patient is 18 years old with stable health, periodic queries for prophylaxis, which ensures a good standard of oral health. Parents were made aware of the importance of preventive treatment.

\section{DISCUSSION}

The dental treatment of patients with social development needs and impaired psychomotor presents challenges, such as impaired communication, severe intellectual deficit, inability to obey commands and follow oral hygiene instructions [3], difficulties in cooperation with the treatment, and fear of strangers [6].

Children treated with an antiepileptic drug are more susceptible to developing periodontal disease. Some researchers speculated that the long-term use of an antiepileptic might be associated with mild and generalized gingival hyperplasia; for example, one side effect of valproate is gingival bleeding [3]. Gingival enlargement is the term used to describe medication-related gingival overgrowth or gingival hyperplasia, a common reactionary phenomenon that occurs due to the use of several types of therapeutic agents, including antiepileptic drugs. Valproic Acid has been linked to gingival overgrowth [10].

The more severe the neurological damage in children with $\mathrm{CP}$, the higher the risk of oral diseases. This occurs because of the greater difficulty that these individuals have to move, perform, or receive an effective oral hygiene, in addition to the limited oral care that this population is exposed. The severity of cognitive and communication ability increases the difficulty for children to express their feelings. The discomfort caused by oral diseases cannot be verbalized and parents may not seek treatment. Therefore, children with severe cognitive impairments are believed to experience pain frequently, most often due to chronic medical conditions associated with their physical disabilities or with medical procedures that aim to manage those conditions [11].

In CP, patients can have neurological abnormalities of digestive system control; therefore, digestive problems are common [12]. In quadriplegics, head control is impaired [13. When there is an inability of coordination between breathing and swallowing, which are represented by neurogenic dysphagia, the individual with CP may present nutritional and immunological deficits; therefore, a doctor might indicate gastrostomy [14].

\section{FINAL CONSIDERATIONS}

Although West's syndrome does not have specific buccal characteristics, care for oral health is of utmost importance to ensure the patient's overall health. All sistemicas features presented in this case report the completion of dental treatment on an outpatient basis, especially when the seizures are not controlled. In this case, despite all the clinical condition of the patient, the dental care was carried out in the office People with disabilities deserve a dental care that contributes to their quality of life. Individuals with SW can have access to dental care if their systemic conditions are respected. Further work on this syndrome is important to improve the knowledge of the professionals who works in this dental specialty. Dental care for people with disabilities should be developed, encouraged and continuously extended, in agreement with the constitutional principles of human dignity and the rights for health and equality.

\section{Collaborators}

CA NACAMURA, developed the experimental part of the study. DM TRIZE, bibliographical survey, article writing. LRC CABELLO, helped in the development of the experimental part of the clinical case. SOB FRANZOLIN, critical article review. SN MARTA, advisor, conception and delineation of the clinical case.

\section{REFERENCES}

1. Shields WD. Infantile spasms: little seizures, big consequences. Epilepsy Currents. 2006;6:3:63-69. http://dx.doi.org/10.1111/ j.1535-7511.2006.0000.x 
2. Carvalho GDA, Lima OB, Melo VC, Silva KL. Actions of nursing care in the infant with WEST syndrome: a case report. J Res Fundamental Care Online. 2014;6:4:1525-33.

3. Khatri A1, Kalra N, Tyagi R, Baweja M, Khandelwal D. Dental findings in patients with West syndrome: a report of two cases. J Indian Soc Pedod Prev Dent. 2014;32(2):168-71. doi: 10.4103/0970-4388.130988

4. Pereira Filho AL, Malucelli DAB, Ferreira LLA, GonçavezD'ottaviano F, Silveira JAM. Avaliação dos achados ao exame dos potenciais evocados do tronco cerebral em indivíduos com síndrome de West. Rev Bras Otorrinolaringol. 2004;70(1):1:90-93. http://dx.doi.org/10.1590/S0034-72992004000100015

5. Wirrell EC, Shellhaas RA, Joshi C, Keator C, Kumar S, Mitchell WG, et al. How should children with West syndrome be efficientlyand accurately investigated? Results from the National Infantile Spasms Consortium. Epilepsia. 2015;56(4):617-25. https://doi.org/10.1111/epi.12951

6. Dantas-Neta NB, de Carvalho e Souza CH, Alencar SMM, Prado Júnior RR, Mendes RF. Dental findings in children with West Syndrome. Spec Care Dentist. 2014;34(6):291-4. doi: $10.1111 / \mathrm{scd} .12068$

7. Liberalesso PBN. Epilepsias na infância: diagnóstico e tratamento. Rev Bras Med. 2007;43:6:274-82.

8. Cardoso AMR, Brito DBA, Alves VF, Padilha WWN. O acesso ao cuidado em saúde bucal para crianças com deficiência motora perspectivas dos cuidadores. Pesqui Bras Odontopediatria Clín Integr. 2011;11(4):593-99.

9. Aguiar SMF, Torres $C P$, Borsatto MC. West syndrome. J Bras Odontopediatr Odontol Bebê. 2003;6(30):123-6.

10. Lin K, Guilhoto LMFF, Yacubian EMT. Drug-induced gingival enlargement - Part II. J Epilepsy Clin Neurophysiol. 2007;13:2:83-88. http://dx.doi.org/10.1590/\$1676-264920 07000200009

11. Abanto J, Carvalho TS, Bönecker M, Ortega AOL, Ciamponi $A L$, Raggio DP. Parental reports of the oral health-related quality of life of children with cerebral palsy. BMC Oral Health. 2012;12:15. http://dx.doi.org/10.1186/1472-6831-12-15

12. Araújo LA, Silva LR, Mendes FA. Digestive tract neural control and gastrointestinal disorders in cerebral palsy. J Pediatr (Rio J). 2012;88(6):455-64.

13. Madalozzo D, Mitre El. Análise da fase oral da deglutição de adultos com paralisia cerebral espástica e tetraplegia. Rev CEFAC. 2004;6(4):345-9.

14. Previtali EF, Santos MTBR. Cárie dentária e higiene bucal em crianças com paralisia cerebral tetraparesia espástica com alimentação por vias oral e gastrostomia. Pesq Bras Odontoped Clin Integr. 2009;9(1):43-47.

Received on: 19/2/2018

Final version resubmitted on: 30/5/2018 Approved on: 17/9/2018 